\title{
The Orthodox Cult as The Source of the Consecrating Education
}

\section{Rafael POVÂRNARU*}

\begin{abstract}
This article aims to emphasize the consecrating attribute of the Orthodox cult and its educative power revealed in the manner in which Orthodoxy communicates faith and also surprised in each person's ability to know and to integrate Christ in his consciousness, ability mirrored by the way of life of every member of the mysterious body belonging to the Son of God.
\end{abstract}

Keywords: Church, Cult, Sacrament, Holy Trinity, Spirituality

Through the pastoral care of the Holy Synod of the Romanian Orthodox Church, the year of 2019 has been dedicated to the evocation of two great personalities of our Church - the Patriarchs Nicodim Munteanu and Iustin Moisescu. Also, this year's intention is to emphasize the spiritual qualities of those who live in the rural parts of the country, even if we are referring to mayors, teachers or householders. The main purpose of our attempt is to relieve the sacerdotal spirituality, but also the laic one, by highlighting the virtues which still define today's Romanian village.

However, all these realities build together a common corpus, as they are all set "under the dome of grace of the

${ }^{*}$ PhD, Hieromonk, Lecturer, Faculty of Orthodox Teology at West University, Timisoara, Romania. 
Church" which has always been provided and will still provide a spiritual education and a cultural one, as well, both manifested as an echo of the authentic living through cult, and, in the same time, as an implicit form of perfecting the human being in his thoroughness.

Therefore, we have to remind the fact that education and culture in our Romanian Orthodox perception have always had an ecclesial origin, as not only the Romanian language is the one which provides to the two words cult - culture a common root, but also "the arts and all the Romanian people's culture originate in cult"1.

In other words, the entire cultural assembly of Romanians has been "imprinted by the Holy Spirit", thus enhancing the whole virtue set inside each man aware of the idea that being close to the Church and living in its spirit has fed the powers of the soul, ensuring in this way the certainty that "the essence of the Romanian culture is the Orthodox Cult"2.

It is the Church's duty to "educate through grace" and it is shown in the moment when the Holy Apostles receive the "the mandate of heaven" - "Therefore go and make disciples of all nations, baptizing them in the name of the Father and of the Son and of the Holy Spirit, and teaching them to obey everything I have commanded you" "3. This is where we can clearly see the intersecting through Christ of the consecrating grace manifested in the sacrament of baptism and the teaching which will always be preached by the Church from the altar of the Son of God. The entire message spread from the Church's pulpit is not just a simple liturgical gesture as it generates an authentic and complete

${ }^{1}$ His Beatitude Daniel the Patriarch of the Romanian Orthodox Church, Cuvânt înainte. Sfânta Liturghie - izvor de viață sfântă și lumină veșnicăa in Liturghier, Bucharest, EIBMBOR, 2012, p. 9.

${ }^{2}$ Ibidem, p. 9.

${ }^{3}$ Matthew 28, 19-20. 
"culture of the Heaven"4 through the power of Christ's consecrating grace.

Therefore, in this piece of writing we intend to highlight in a very concise manner all the reasons mentioned above.

\section{The Cult as the Dialogic Encounter of Heaven with Its Own "Icon"}

We all know from the Old Testament that Adam was created in God's image and likeness ${ }^{5}$, having "the heavenly

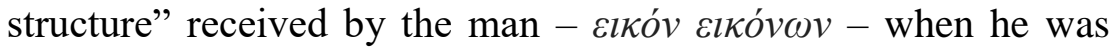
given "the breath of live" consecrated by God in his relationship with the man, commanding our first parents to "be fruitful and increase in number; fill the earth and subdue it" ${ }^{\text {" }}$, giving them the freedom to feed themselves from any tree in Heaven, "but of the tree of the knowledge of good and evil"s.

These words are the proof of the unlimited communication between man and God since the very beginning, the man being invited to an "endless Amen"9 as a personal answer vowed to his Creator. Also, from these lines we can see God's calling addressed to Adam and Eve to "be fruitful and increase in number". Being fruitful refers mainly to a spiritual growth, as it is

${ }^{4}$ His Holiness Ioan the Metropolitaan of Banat, Pastorala de Crăciun, http://mitropolia-banatului.ro/pastorala-de-craciun-2016/, accessed in November $29^{\text {th }} 2018$.

5 "Let us make mankind in our image, in our likeness, so that they may rule over the fish in the sea and the birds in the sky, over the livestock and all the wild animals, $\left.{ }_{\underline{a}}\right]$ and over all the creatures that move along the ground" Genesis 1, 26.

${ }^{6}$ Genesis $2,7$.

${ }^{7}$ Genesis 1, 28.

${ }^{8}$ Genesis 2, 17.

${ }^{9}$ His Holiness Irineu Slătineanul, „Martiriul ca jertfă euharistică”, in Viața liturgică și etos comunitar. Preliminarii la o teologie socială ortodoxă, Craiova, Mitropolia Olteniei Press, 2007, p. 18. 
well known that the first men were not perfectly accomplished, even though the protestant beliefs assume the opposite, position completely contradicted by the entire Tradition of the Church. Thus, our first parents were given the gift of trying to become accomplished, this quality could only be achieved as a personal expression of each man's will to be united with God.

Since the very beginning, between the Creator and His creation an act of cult was set, based on the expression of the reciprocal love as the principle of the spiritual echo of listening, also a virtue further "to be perfected". Therewith, besides the already mentioned dialogue, itself defined as a prayer, "the space of primordiality" provides us a very important act of cult when it comes to consecrating the human being - we notice the first fasting known by humanity through its first fathers. Not feeding from the forbidden tree means precisely the complete exercise of defeat through which Adam and Eve set themselves in prayer, in the accomplished state of a synergic act. All these were manifesting "in the space of heavenly dimension of the Church", there where the man finds himself in a permanent communion with God.

In this state of thorough obedience and practicing with love for his Creator all the necessary reasons as "wings of the Holy Spirit", the man could know in this way the faultlessness, getting used with the perspective of gaining the strength to oust the temptations which the devil, disguised as a snake, was about to launch not only against the man, but through him, against the entire creation. This is why, after Adam and Eve's falling from Eden, all reality had to experience the effects of death.

This image provided us the cultic act found in the undiminished dialogue between man and God and also a sort of "education of the Holy Spirit" that must be reached by man as an exclusive gesture of communion. 
Theology takes these aspects into consideration when it defines the cult as "any form or religious act meant to place the human being in relationship with God, on one hand expressing the honor and respect towards God and on the other hand mediating the consecration of man or communing the divine grace" 10 .

Therefore, the Church - space of "making time and man eternal"11 - projects through Its way of living, vivid through grace in the cultic act, the entire "itinerary of faultlessness which can be found in the Book of Genesis".

From here it derives the characteristic "triad" of the cult, to be more precise: the charismatic or the consecrating one, the latreutic and the didactic or educational one, through which the Orthodox cult is defined ${ }^{12}$. It can be observed how the whole synergic gesture included in each cultic act can be projected and classified as an "educational" act emphasized by each prayer, song or icon, all capable of realizing an intimate dialogue between God and man, its purpose being accomplishing the latter.

Exclusively based on Christ's example, the Orthodox cult's defining attribute is the immediate sharing of the divine gifts with the entire creation and especially with the man, gifts sprung from the Son of God who through His triple role - as King, Bishop and Teacher - becomes the archetypal model of obeying the Father in the name of love for Him, expressed in the permanent calling to fast, to pray and to be present to the Father's presence ${ }^{13}$, according to Christ's saying while talking to His Mother and to Saint Joseph and while reading the holy books in the Temple.

10 Ene BRANIȘTE, Liturgica generală cu noțiuni de artă bisericească, arhitectură și pictură creștină, Bucharest, EIBMBOR, 1993, p. 45.

11 Dumitru STĂNILOAE, Trăirea lui Dumnezeu in Ortodoxie, Cluj-Napoca, Dacia Press, 1993, p. 115.

${ }^{12}$ Ene BRANișTE, op. cit., p. 62-67.

${ }^{13}$ Luke 2, 49. 
These realities surprised by the New Testament portray Jesus Christ the Man as the absolute icon of the cultic manifestation - token of love and obedience towards the Father. In other words, each time when a Christian attends the Church and manages to extend this way of feeling inside "the living cell of the Secret Body of Christ"14 which is the family as a "Liturgy after a Liturgy"15, through his thoughts and gestures always committed to God, he succeeds to transform his own life in the honest sacrifice placed at the Heaven's door. In this way, the man will be able to rejoice the experience of receiving God's reward with "his soul's eyes", according to the profound words of the Evangelic Pericope of the Meatfare Sunday which describe this reward as "logos towards humanity"16 - "Come, you blessed of My Father, inherit the kingdom prepared for you from the foundation of the world"17.

Through life and continuous reference to God, not only would the man gain the virtue and accomplish a cultic act, but all these surrounded by the Holy Spirit's grace would generate an endless education of the spiritual senses and of the physical ones, as well. Once transformed under Christ's intention, they will feel the undiminished joy so beautifully expressed by Saint Paul the Apostle in the following lines: "I have been crucified with Christ; it is no longer I who live, but Christ lives in me; and the life which I now live in the flesh I live by faith in the Son of God, who loved me and gave Himself for me"18.

${ }^{14}$ Laurenţiu STREZA (currently the Archbishop of Sibiu and the Metropolitan of Ardeal), in Vasile GAVRILĂ, Cununia - viața intru impărăție, Bucharest, „Tradiţia Românească” Foundation, 2004, p. 2.

${ }^{15}$ Ioan BRIA, Liturghia după Liturghie. O tipologie a misiunii apostolice și mărturiei creștine azi, Athena Press, Bucharest, 1996.

${ }^{16}$ Father Professor Dumitru Stăniloae, op. cit., p. 113.

${ }^{17}$ Matthew 25, 34.

${ }^{18}$ Galatians 2, 20. 
Consequently, from these words we understand that once baptized and sat inside the grave together with Christ, through the sacrament of baptism, the man assumes God's cross as an uninterrupted state of sacrifice accomplished through God's sanctifying Passions. By becoming an ecclesial being ${ }^{19}$, the baptized man lifts his cross according to our Redeemer's words "Whoever desires to come after Me, let him deny himself, and take up his cross, and follow Me" 20 . The cross "hidden with Christ in God" 21 will determine an endless dialogue born "from the Cross" which will embrace the holy image of a cultic act derived from the reciprocal love by means of which the man will be consecrated through the Holy Spirit's grace, therefore becoming capable of knowing God Himself.

Hence, we can observe how by the sanctifying power of the cultic act effected in the Church each Christian gets to know "Christ's mind" 22 which, once acquired, would not only shape the conscience, but also show the entire world the real "enhypostasis of Christ" founded on love and sacrifice, capable to imprint the humanity a new and, in the same time, a 2000 years old paradigm of education with and through Christ.

\section{Education as a Cultic Act}

Considering all the observations mentioned in our previous lines, it is required to mention here the theologist Alexander Schmemann who said that by the sacrament of baptism the

${ }^{19}$ Ioannis ZizIOULAS, Metropolitan of Pergam, Fiinţa eclesială, Bucharest, Bizantin Press, 2007.

${ }^{20}$ Mark 8, 34.

${ }^{21}$ Colossians 3, 3 .

${ }^{22}$ Saint Nicholas Cabasilas, Despre viaţa în Hristos, Bucharest, IBMBOR Press, 2009, p. 115. 
Christian receives Christ together with his three attributes ${ }^{23}$. This reality brings together a certain manifestation of man not just towards himself, but especially towards God, and through Him, towards the world. In this way, by the joy of being "imprinted by the Holy Spirit", the Christian receives all the potential spiritual gifts $^{24}$ and he is called to fulfill them in his dialogue with God. But "as the bearer of grace", the baptized man always has to share his gifts to those who need them, being convinced that in this way, as Christ teaches us, "Assuredly, I say to you, inasmuch as you did it to one of the least of these My brethren, you did it to Me" ${ }^{\prime 25}$. This means that the meeting between God and each one of us can happen including when we put ourselves in the service of the others. Therefore, through this exercise, the Christian builds his love on the love and sacrifice he owes the Heaven, his dialogue with the world giving to the latter the joy of knowing "God and with God" as a consequence of his own cultic act performed through his relationship with the Father.

Thus, besides the immediate knowledge of the Holy Trinity and of the entire Orthodox teaching provided by cult through the Holy Gospel, the Cross, prayers, canticles, icons, hymnographic poetry etc., each attempt of dialogue between Christians becomes a cultic act, originating in the very essence imprinted by the Christic presence and by the Holy Spirit's aura in a much wider sense, but unquestionably built after the model of Christ.

In this key, the attempt of teaching the others in the spirit of Christ's Cross, impregnated by the blood of Sacrifice and, in the same time, enlightened by the grace of the Resurrection receives the echo of Heaven.

23 Alexander SchmemAnN, Din apă şi din Duh - un studiu liturgic al Botezului, Bucharest, Sophia Press, 2009, p. 112-113.

24 "But the fruit of the Spirit is love, joy, peace, longsuffering, kindness, goodness, faithfulness, gentleness, self-control" - Galatians 5, 22-23. ${ }^{25}$ Matthew 25, 40. 
Therefore, besides the aspects previously mentioned the Church has other forms of cult in which the essence of the consecrating education can be found. In this way, each sermon which accompanies the liturgical service, the priest, either bishop or deacon, shares with the audience the word full of divine pedagogy contained by the Holy Gospel.

Furthermore, by their alive and dynamic missionary spirit, the Church's servants organize series of catecheses meant to give answers, according to the age of the present members - children, youngsters, adults or elder people - to their curiosities and to their pastoral necessities. From this point of view, even if we are referring to a sermon or to a catechesis program, both are cultic acts of the educational area belonging to the Orthodox Church.

Through each cultic gesture, the Church becomes, not just a simple school of reason, but in the same time it determines our conscience to learn how to get used to praying, fasting, forgiving and especially loving, as its Head is our Redeemer Himself. All these have a divine origin as they have been manifested by our Lord during his passage on Earth as Human. Knowing all of these through the Ekklesia ( $\dot{\varepsilon} \kappa \kappa \lambda \eta \sigma i ́ \alpha)$ and by making the conscience work together with God's grace, the man becomes from apprentice a real student, in this way capable of sharing with the others the gifts he acquired from "the School of the Heaven".

These realities become afterwards the appanage of an authentic act of spiritual education first provided by the mother and by the father inside the Christian families, there where, through Christ, each member has to integrate all these customs as they are capable to inoculate the mutual respect, the true love, the reciprocal obedience to Christ, but also pure feelings of pudicity, restraining and justice. When these attributes are "metabolized" inside the intimate body of the family, its members receive God's blessing at all the times. 
In the same time, another educative cultic act takes place in schools. Here, the God-fearing teacher, aware that his mission is to shape consciences for God's Kingdom, shares to the audience not just his intellectual heritage, but especially his gifts received through science from his Creator. In other words, even though the syllabus involves a continuous personal effort to integrate and to improve the knowledge, none of these can be possible without God's help, as His words clearly say: "apart from me you can do nothing" 26 , meaning that the Holy Trinity represents the absolute Good. It is proper to highlight the fact that this synergy is valid not only for those who teach religion and who studied this field and who know how to share the Word, but for all those who are aware that education finds its real and complete essence in God's person, as we all know that $\mathrm{He}$ is " the way and the truth and the life"

Moreover, regarding the laity, each Christian can accomplish an act of cult with a powerful educational, motivational and mainly spiritual impact when he loves, forgives and shares his whole affection when he offers an embrace, as all these manifestations are practiced and lived through Christ, during the Holy Liturgy. There, every time, if we are either clerics or believers, we all are taught to "love one each other" in the moment when all the priests share the "embrace of peace" and the laics should follow their example. Unfortunately, this ritualic gesture of reciprocal forgiveness and love manifested by putting the hearts together has diminished in time.

In conclusion, we see how through Its entire cult, the Church has shared continuously Its teaching, being aware of the fact that not only the altar or the nave's pulpit represent the spaces of the endless evangelic teaching, but also each Christian

26 John 15, 5.

27 John 16, 6. 
heart can completely assimilate the "teaching dignity" given by the Holy Liturgies as a consecrating token born from worshiping God by "integrating Christ". Thus, through our God as Father, Son and Holy Spirit, the Church will always be a school of virtue where "every believer has to be [and to remain] God's man" 28 .

\section{References}

1. BRANIȘTE, Ene, Liturgica generală cu noțiuni de artă bisericească, arhitectură și pictură creștină, Bucharest, EIBMBOR, 1993.

2. BRIA, Ioan, Liturghia după Liturghie. O tipologie a misiunii apostolice și mărturiei creștine azi, Athena Press, Bucharest, 1996.

3. Saint NicholaA CABASILAS, Despre viaţa in Hristos, Bucharest, IBMBOR Press, 2009.

4. DANIEL, the Patriarch of the Romanian Orthodox Church, Cuvânt înainte. Sfânta Liturghie - izvor de viață sfântă și lumină veșnică, in Liturghier, Bucharest, EIBMBOR, 2012.

5. PĂRĂIAN, Teofil, Credinta mărturisitoare, Bucharest, EIBMBOR, 2009.

6. SCHMEMANN, Alexander, Din apă şi din Duh-un studiu liturgic al Botezului, Sophia Press, Bucharest, 2009.

7. SlĂTINEANUl, Irineu, „Martiriul ca jertfă euharistică”, in Viața liturgică și etos comunitar. Preliminarii la o teologie socială ortodoxă, Mitropolia Olteniei Press, Craiova, 2007.

8. StĂNiloAe, Father Professor Dumitru, Trăirea lui Dumnezeu în Ortodoxie, Dacia Press, Cluj-Napoca, 1993.

9. STREZA, Laurenţiu (currently the Archbishop of Sibiu and the Metropolitan of Ardeal) in the Foreword of Father Dr. Vasile Gavrilă, Cununia - viața intru impărăție, "Tradiția Românească” Foundation, Bucharest, 2004.

${ }^{28}$ Father Archimandrite Teofil Părăian, Credinta mărturisitoare, E.I.B.M..O., Bucharest, 2009, p. 159. 
10. ZIZIOULAS, Ioannis, Metropolitan of Pergam, Fiinţa eclesială, Bizantin Press, Bucharest, 2007.

\section{Web sources:}

11. Ioan the Metropolitaan of Banat, Pastorala de Crăciun, http://mitropolia-banatului.ro/pastorala-de-craciun-2016/, accessed in November 29th 2018.

12. https://www.biblegateway.com/. 